Asian J. Med. Biol. Res. 2020, 6 (4), 650-658; doi: 10.3329/ajmbr.v6i4.51231

\author{
Asian Journal of \\ Medical and Biological Research \\ ISSN 2411-4472 (Print) 2412-5571 (Online) \\ www.ebupress.com/journal/ajmbr
}

\title{
Article \\ Functionality of Elaeocarpus serratus leaves on growth, meat quality and cost return analysis in broiler rearing
}

Md. Manirul Islam ${ }^{1 *}$, Meherunnesa Chowdhury Sumy ${ }^{2}$, Kona Adhikary $^{1}$ and Priunka Bhowmik ${ }^{1}$

${ }^{1}$ Department of Animal Science and Nutrition, Faculty of Veterinary Medicine, Chattogram Veterinary and Animal Sciences University, Zakir Hossain Road, Khulshi, Chattogram - 4225, Bangladesh

${ }^{2}$ Department of Agricultural Economics and Social Sciences, Faculty of Veterinary Medicine, Chattogram

Veterinary and Animal Sciences University, Zakir Hossain Road, Khulshi, Chattogram - 4225, Bangladesh

${ }^{*}$ Corresponding author: Md. Manirul Islam, Department of Animal Science and Nutrition, Faculty of Veterinary Medicine, Chattogram Veterinary and Animal Sciences University, Zakir Hossain Road, Khulshi, Chattogram 4225, Bangladesh. Phone: +8801712736518; E-mail: mrislamcvasu @ gmail.com

Received: 31 October 2020/Accepted: 02 December 2020/ Published: 31 December 2020

\begin{abstract}
The study was conducted to evaluate the effects of olive leaves with probiotics (OLP) on growth performance, carcass characteristics, meat quality, blood parameters and oxidative stability of meat in broiler. A total of 160 day old, unsexed Cobb-500 chicks were distributed in to five dietary treatment groups: Control (Basal diet), OLP-1 (Basal diet $+0.4 \%$ OLP, DM basis), OLP-2 (Basal diet + 0.8\% OLP, DM basis), OLP-3 (Basal diet $+1.2 \%$ OLP, DM basis) and OLP-4 (Basal diet $+1.6 \%$ OLP, DM basis) having 4 replications with 8 birds in each in a completely randomized design. Results showed that the live weight, overall average daily gain $(A D G)$ increased significantly $(\mathrm{p}<0.05)$ in all treatment groups compared to control. The weekly feed conversion ratio $(\mathrm{FCR})$ reduced significantly $(\mathrm{p}<0.05)$ in $0-14$ days and the weekly ADG improved in 15-28 days. Blood cholesterol and high density lipoprotein (HDL) increased significantly $(\mathrm{p}<0.05)$ in all treatment groups except OLP-4 compared to control. The dressing percentage showed significant $(\mathrm{p}<0.05)$ difference among treatment groups and control. Organs weight were similar among treatment groups, although the breast meat and bursa weight differed significantly $(\mathrm{p}<0.05)$ in treatment groups. A significant increase $(\mathrm{p}<0.05)$ in meat crude protein (CP) and total ash content in treatment groups relative to control. Meat thiobarbituric acid reactive substances (TBARS) significantly $(\mathrm{p}<0.05)$ decreased at $0.8 \%, 1.2 \%$ and $1.8 \%$ during $1^{\text {st }}, 2^{\text {nd }}, 3^{\text {rd }}$ weeks and in average value as well. Net return and benefit cost ratio (BCR) substantially increased in all treatment groups compared to control $(\mathrm{p}<0.05)$. Finally, dietary OLP supplementation improved growth performance, meat CP and ash content, increased blood cholesterol, HDL content, net rutrun and BCR while reduced meat TBARS value. Thus, olive leaf probiotics can be a potential source to be used as feed additive in broiler.
\end{abstract}

Keywords: broiler; olive leaves; probiotics; growth performannce; meat quality; BCR

\section{Introduction}

Broiler farming seems to be a considerable part of meat industry all over the world. The broiler industry has been threatened because of the use of antibiotics as growth promoter in sub-therapeutic doses which can exert health hazard by depositing antibiotic residue in human body (Muaz et al., 2018). Considering that, antibiotics were restricted in broiler diet to be used as a growth promoter. Despite that, farmers often use commercial feeds containing antibiotics and also violate the rules of antibiotic usage (Wasnaeni et al., 2015). This opened a necessity for the use of an alternative growth promoter in broiler with no adverse effect on human health, promisingly natural products. Among many other plants, Ceylon olive (Elaeocarpus serratus) leaves which has been used as a medicinal plant, can be a potential source to serve the purpose. Olive leaves contain many secondary metabolites such as saponins, tannins, cardiac glycosides, flavanoids, phytosterol, steroids and antioxidant like ascorbic acids (Das et al., 2017). The leaves of E. serratus also contains fatty acids, 
hydrocarbons, alcohols, alkenes and aldehydes (Geetha et al., 2013). Olive leaves also have antibacterial effects whereas the plant extract have antifungal effects (Jayashree et al., 2014). Ethanolic extract of Ceylon olive leaves possesses antibacterial and cytotoxic activity (Biswas et al., 2012). Olive leaf extracts are seen to improve feed intake, weight gain and feed conversion ratio in broiler (Oke et al., 2017). In broiler, the leaves cause an improvement in oxidative stability, physio-chemical and sensory characteristics of meat (Marangoni et al., 2017).

Although Ceylon olive leaves are available throughout the country, the most suitable method of feeding and formulation are needed to be determined. This study was designed to evaluate the functionality of Ceylon olive leaves with probiotics on the growth performance, meat quality, oxidative stability and cost return analysis of broiler rearing.

\section{Materials and Methods}

\subsection{Preparation of olive leaves probiotics (OLP)}

After collection of olive leaves from Chattogram region, they were washed, cleaned and air dried. Then, those were ground by an electric grinder (Panasonic MX-AC555). The probiotics cultures (Lactobacillus plantarum KCTC 3104 and Saccharomyces cerevisiae KCTC 7915) were purchased from the Add Bio Bd Inc., Dhaka Bangladesh. MRS broth (HiMedia Laboratories Pvt. Ltd., India) and YM broth (HiMedia Laboratories Pvt. Ltd., India) used for growth of Lactobacillus plantarum and Saccharomyces cerevisiae respectively as per instructions of the company.

For solid state fermentation, deoiled rice bran and distiller's dried grains with solubles (DDGS) were used as media. $1 \%$ of Lactobacillus plantarum KCTC 3104 and $1.0 \%$ of Saccharomyces cerevisiae KCTC 7915 were added to the olive leaves and made it's moisture content about $40 \%$ to make the fermentation process properly by adding adequate distilled water. The mixture was then incubated at $37^{\circ} \mathrm{C}$ for 3 days (Incubator model: LGI-150T, Labnics®, USA). The formulated probiotics mixtures were air dried for 2 days until the moisture level was less than $15 \%$ using a dry oven (Labnics®, USA).

To determine the concentration of probiotics in OLP, 10-fold serial dilution were performed and then cultured in MRS agar (Hi-media ${ }^{\circledR}$, Ref:M641-500G) and Potato Dextrose agar (Hi-media®, Ref:M096-500G) for growth of Lactobacillus plantarum and Saccharomyces cerevisiae respectively after which the number of colonies was counted by colony counter and expressed as cfu/gm (Table 1).

\subsection{Experimental birds, diet and treatment}

A total of 160 day old, unsexed Cobb-500 chicks were distributed in to five dietary treatment groups: Control (Basal diet), OLP -1 (Basal diet + 0.4\% OLP, DM basis), OLP -2 (Basal diet + 0.8\% OLP, DM basis), OLP -3 (Basal diet $+1.2 \%$ OLP, DM basis) and OLP -4 (Basal diet $+1.6 \%$ OLP, DM basis) having 4 replications with 8 birds in each in a completely randomized design.

A maize and soybean meal-based iso-caloric and iso-nitrogenous diet was prepared for both the starter and grower stage according to the nutrient requirements broiler chickens (NRC, 1994). The starter diets were offered from day 1 to day 14 , while grower diets were provided from day 15 to day 28 . The proximate composition of dried OLP and basal diet (starter and grower) were determined by the method described by the Association of Official Analytical Chemists (AOAC, 2000). The ingredients and nutrient compositions of the experimental diets are shown in Table 2. Birds were kept in a close ventilated, wire-floor caged broiler house $(90 \mathrm{~cm}$ long $\times$ $80 \mathrm{~cm}$ wide $\times 40 \mathrm{~cm}$ high/cage) at a stocking density of $720 \mathrm{~cm}^{2} /$ bird and supplied with ad libitum feed and water throughout the experimental period.

\subsection{Growth Performance}

The body weight and feed consumption was recorded per pen on a weekly basis from the initial day to the final day of the experiment. Then feed conversion was calculated as feed consumed divided by body weight gain per pen.

\subsection{Carcass characteristics}

At the end of the feeding trial (day 28), birds were randomly selected from each replicate and sacrificed according to Muslim (Halal) method by severing the jugular vein and carotid artery. The birds were dressed following Jones (1984) method and dressing percentage were calculated. Different organ and body part such as thigh, breast, abdominal fat, liver, spleen, bursa, caecum, total intestine and gizzard were weighed. 
2.5. Meat sampling and analysis

The breast meat sample were collected and stored at $-20^{\circ} \mathrm{C}$ until analysis. The proximate composition and oxidative rancidity of the meat were determined. For proximate analysis, meat samples were analyzed in triplicate for moisture (934.01), crude ash (942.05), crude protein (988.05), and ether extract (920.39) as described by AOAC (2000).

To determine the oxidative stability, meat samples were preserved in a refrigerator at $4^{\circ} \mathrm{C}$, after which thiobarbituric acid reactive substance (TBARS) values of meat were assayed when fresh as well as at 1, 2, and 3 weeks according to the modified method described by Du and Ahn (2002). Briefly, $4 \mathrm{~g}$ of each sample was mixed with a $10 \mathrm{ml}$ solution composed of $2 \mathrm{M}$ phosphoric acid and $20 \%$ trichloroacetic acid. The mixture was then diluted with $10 \mathrm{ml}$ of distilled water and homogenized by homogenizer and filtered through Whatman No. 1 filter paper. Following filtration, $2 \mathrm{ml}$ of the filtrate were transferred to a test tube, after which $2 \mathrm{ml}$ of 2thiobarbituric acid $(0.005 \mathrm{M}$ in DW) was added. The sample test tube was kept in 80 degree celsius in a hot water bath for $30 \mathrm{~min}$. The absorbance was measured using a Spectrophotometer at $530 \mathrm{~nm}$. TBARS values are expressed as $\mu \mathrm{mol}$ of malondialdehyde (MDA) per $100 \mathrm{~g}$ of meat.

\subsection{Hematological analysis}

After collection of blood, serum was separated from which different blood parameters (cholesterol, triglyceride, LDL and HDL) were measured in automatic analyzer (Humalyzer 300, Merck ${ }^{\circledR}$, Germany) according to the manufacturer's instruction (FVMAAU; Addis Ababa, Ethiopia).

\subsection{Cost and return analysis}

Cost and return was calculated based on recurrent and fixed cost, while return was calculated on sale of birds per unit. Recurrent cost included cost of bird, labour, feed, medicine, vaccine, electricity and miscellaneous cost. Whereas fixed included housing and equipment cost. Finally net return and BCR was calculated based on total cost and total return.

\subsection{Statistical analysis}

All the data were analyzed following the General Linear Model (GLM) procedure using the Statistics Analysis Systems Institute employing polynomial analysis (version 9.1; SAS Ins. Inc., Cary, NC, USA). Individual cages served as an experimental unit and a group of two birds served as the experimental units for organ weight, meat composition, and oxidative stability. Treatment means were computed with the LSMEANS option of the SAS program and a probability level of $\mathrm{p} \leq 0.05$ was considered statistically significant.

\section{Results and Discussion}

\subsection{Growth performance}

The dietary effects of OLP on growth performance of broiler of 4 weeks growth trial are presented in Table 3 . Results showed a significant $(\mathrm{p}<0.05)$ increase in overall live weight in all treatment groups compared to control. There was a significant increase in average daily gain (ADG) observed in all dietary groups than control from 0-28 days of age where the highest gain was observed in OLP-4 group $(38.74 \mathrm{~g} / \mathrm{b} / \mathrm{d})$ suppled with $1.6 \%$ OLP in diet. During 15-28 days, the weekly ADG has also increased and average feed intake (ADFI) decreased significantly $(\mathrm{p}<0.05)$ in treatment groups compared to control. The overall ADFI reduced significantly $(\mathrm{p}<0.05)$ in all dietary groups than control. The feed conversion ratio (FCR) decreased significantly $(\mathrm{p}<0.05)$ in all treatment groups than the control group.

In a study conducted in Saudi Arabia, olive leaves containing $85 \mathrm{~g}$ crude protein, $45 \mathrm{~g}$ crude fat, $149.9 \mathrm{~g}$ crude fiber and $96.9 \mathrm{~g}$ ash (Shafey et al., 2013). The proximate composition tested in this study showed that olive leaves contain a great amount of protein $(10.41 \%)$ and ash $(6.75 \%)$ may be due to geographic and climatic change.

A study by Shafey et al. (2013), showed that body weight increased at $3^{\text {rd }}$ week of age with $15 \mathrm{~g} / \mathrm{kg}$ feed but reduced with 30 and $50 \mathrm{~g} / \mathrm{kg}$ feed. In our study, the highest live weight gain was found in $1.6 \%$ OLP which is close to Shafey et al. (2013). In an experiment, higher ADG and lower FCR were observed in olive pomace extract supplied (750 ppm) group than control in broiler (Herrero-Encinas et al., 2020). Another study revealed that daily body weight gain, feed intake and FCR improved in all treatment groups supplied with alcoholic extract of olive leaves (Erener et al., 2020). These results showed similarity with that of the present study. The final weight, ADG and FCR have improved remarkably in different treatment groups in this study, may be due to fermentation and the microflora improved digestibility of feed. Lactobacillus plantarum enhanced ADG and FCR in broiler in an experiment by Peng et al. (2016). 


\subsection{Hematological parameters}

Supplementation effects of olive leaves probiotics are displayed in Table 4. The blood cholesterol shows significant $(\mathrm{P}=0.05)$ difference where the lowest found in OLP-4 $(143 \mathrm{mg} / \mathrm{dl})$. There was significant $(\mathrm{P}<0.05)$ rise in HDL level in all treatment groups compared with control except OLP-4 (46.88 mg/dl). The triglyceride and LDL level remained static.

A study by Erener et al. (2020) revealed that plasma cholesterol and HDL increased in all treatment groups compared to control which shows similarity with the current study findings. Furthermore, cholesterol level increased with $2 \%$ supplementation of olive leaf meal in diet in broiler whereas the TG, LDL level remained unaffected (Sateri et al., 2017). Another experiment in broiler by Nafea and Hussein (2018) showed that HDL and LDL in serum increased while cholesterol decreased with 5,10 and $15 \mathrm{~g} / \mathrm{kg}$ olive leaf power supplement in diet. The highest level (1.6\%) of olive leaf in diet significantly reduced cholesterol level may be due to the presence of phenolic compounds in leaves which proved to have hypocholesterolemic effect in rats (Fki et al., 2007). The cause of increased HDL and LDL in serum may be due to the presence of vitamin $E$ in olive leaf which showed to decrease the oxidative susceptibility of HDL and LDL (Arrol et al., 2000). In contrast, a study found that probiotic, Lactobacillus plantarum lowered the cholesterol, in serum in rats though no significant differences was found in serum HDL level (Huang et al., 2013).

\subsection{Relative meat yield and internal organs weight}

Relative internal organs weight, presented in Table 5, shows that the dressed weight and relative breast meat weight were significantly different $(\mathrm{p}<0.05)$. The weight, length and width of thigh bone showed no notable changes from control. Among internal organs, the relative weight of bursa differed significantly $(\mathrm{p}<0.05)$ where the highest $(0.28 \mathrm{~g})$ was in OLP-2 and the lowest $(0.13 \mathrm{~g})$ in OLP-1.

Shafey et al. (2013) reported no significant effect of olive leaves on carcass characteristics with a significant reduction of the eviscerated carcass weight when $15,30,50 \mathrm{~g} / \mathrm{kg}$ wheat bran are substituted by olive leaves in broiler. Another study by Omar (2005) showed that carcass characteristics remained unaffected by the supplementation of olive pulps in broiler. The relative breast weight increased may be because of the inoculation of probiotics along with olive leaves. A study reported diet containing commercial probiotics increased breast percentage in broiler (Mehr et al., 2007).

\subsection{Meat composition}

Dietary effects of OLP in proximate composition of meat are represented in Table 6. There was a significant increase of CP in all treatment groups than control (22.05) except in OLP-4 (21.65). The highest CP found in OLP-1 (23.45). There was a highly significant $(\mathrm{p}<0.001)$ relation found in ash content of meat where the lowest (1.44) in control and highest (1.68) in OLP-2.

In this experiment, the probiotics along with olive lives may result in the increase of CP\% and Ash\%. Olive leaves contains a significant amount of sodium, calcium, potassium, iron and some others like copper, magnesium, zinc and phosphorus (Chand and Azeez, 2018). The minerals may increase the ash percentage of meat. A study conducted by Khaksefidi and Rahimi (2005) concluded that probiotics in diet increased the moisture, CP and Ash in leg and breast meat of broiler. Podolian (2017) stated that calcium, phosphorus, iron, zinc, magnesium and copper increased in thigh muscle of poultry which resulted in higher ash content of meat. Same study found that probiotic in broiler diet increased the synthesis of essential amino acids in pectoral muscle such as lysine, histidine, arginine, threonine, valine, methionine, leucine and phenylalanine. This ultimately resulted in the increase of protein percentage of meat.

\subsection{Meat thiobarbituric acid reactive substances (TBARS) value}

The effects of OLP in TBARS value of breast meat are shown in Figure 1. No significant difference was observed in the fresh meat sample. But a significant reduction was noted in first to third weeks in comparison with control $(\mathrm{p}<0.05)$. Furthermore, average TBARS value was significantly reduced compared to control $(\mathrm{p}<0.05)$.

The treatments with addition of olive leaves via broiler feed showed lower peroxide values was capable of delaying the onset of oxidative process (Marangoni et al., 2017). The causes of reduction of TBARS value is due to the synergistic effects of olive leave that contains phenolic compounds which scavenges free radicals (Devatkal et al., 2010) and probiotics which also act as antioxidant (Wang et al., 2017). 


\subsection{Cost and return analysis}

Cost and return analysis is represented in Table 7. According to the results, significant variation was found for recurrent cost, total cost, total return, net return and benefit cost ratio (BCR). Higest total cost was found in control whereas lowest total cost was in $0.8 \%$ fermented olive leaves group $(\mathrm{p}<0.01)$. Maximum net return and BCR was calculated in fermented olive leaves group compared to control and other treatment $(\mathrm{p}<0.05)$. The findings of this current study is agree with Hossain et al. (2019) who reported that $0.4 \%$ fermented elephant apple leaf showed higher BCR than non fermented leaves group.

Table 1. Microbial concentration and nutrient composition of olive leaves probiotics (OLP).

\begin{tabular}{ll}
\hline Item & Olive leaves probiotics (OLP) \\
\hline Microbial stains in (OLP) (cfu/gm) & \\
Lactobacillus plantarumKCTC 3099 & $2.4 \times 10^{9}$ \\
Saccharomyces cerevisiae KCTC 7928 & $1.9 \times 10^{9}$ \\
Chemical composition & \\
Dry matter (\%) & $98.80 \pm 0.06$ \\
Crude Protein (\% dry matter) & $10.41 \pm 0.25$ \\
Crude Fat (\% dry matter) & $2.60 \pm 0.12$ \\
Crude Fiber (\% dry matter) & $23.05 \pm 0.23$ \\
Crude Ash (\% dry matter) & $6.75 \pm 0.06$ \\
pH & $4.07 \pm 0.02$ \\
\hline
\end{tabular}

Table 2. Ingredients and nutrient composition of experimental diet.

\begin{tabular}{lll}
\hline $\begin{array}{l}\text { Ingredients } \\
\text { (as \% feed basis) }\end{array}$ & $\begin{array}{l}\text { Starter } \\
(\mathbf{0 - 1 4} \text { days) }\end{array}$ & $\begin{array}{l}\text { Grower } \\
\text { (15-28 days) }\end{array}$ \\
\hline Corn & 52.00 & 53.00 \\
Wheat & 2.00 & 2.00 \\
Rice polish & 2.50 & 3.20 \\
Soybean meal & 32.00 & 29.20 \\
Fishmeal & 4.00 & 3.50 \\
Palm oil & 3.50 & 5.00 \\
DCP & 1.79 & 1.79 \\
Limestone & 1.15 & 1.15 \\
NaCl & 0.30 & 0.30 \\
Choline chloride & 0.06 & 0.06 \\
Vitamin min premix ${ }^{1}$ & 0.15 & 0.15 \\
L-lysine & 0.40 & 0.40 \\
DL-methionine & 0.22 & 0.22 \\
Toxin binder & 0.25 & 0.25 \\
Enzymes & 0.04 & 0.04 \\
Chemical composition (as fed basis) $^{3}$ & & \\
ME (kcal/kg) & 3001.65 & 3104.85 \\
Crude protein \% & 22.09 & 20.71 \\
Crude fiber \% & 3.76 & 3.68 \\
Ether extract \% & 3.67 & 3.68 \\
Lysine\% & 0.72 & 0.80 \\
Calcium\% & 1.30 & 1.26 \\
Phosphorus\% & 0.72 & 0.70 \\
\hline
\end{tabular}

${ }^{1}$ Vitamin-mineral mixture provided the following nutrients per kg of diet: Vitamin A 15,000 IU, Vitamin D3 1500 IU, Vitamin E 20.0mg, Vitamin K3 $0.70 \mathrm{mg}$, Vitamin B12 $0.02 \mathrm{mg}$, Niacin $22.5 \mathrm{mg}$, thiamin $5.0 \mathrm{mg}$, folic acid $0.70 \mathrm{mg}$, pyridoxine $1.3 \mathrm{mg}$, riboflavin $5 \mathrm{mg}$, pantothenic acid $25 \mathrm{mg}$, choline chloride $175 \mathrm{mg}$, Mn $60 \mathrm{mg}$, Zn $45 \mathrm{mg}$, I $1.25 \mathrm{mg}$, Se $0.4 \mathrm{mg}$, Cu $10.0 \mathrm{mg}$, Fe $72 \mathrm{mg}$, Co $2.5 \mathrm{mg}$, (Arif's Bangladesh Ltd., Bangladesh). 
Table 3. Effects of dietary supplementation of OLP on growth performance in broiler.

\begin{tabular}{|c|c|c|c|c|c|c|c|}
\hline \multirow{2}{*}{ Parameters } & \multicolumn{5}{|c|}{ Treatments } & \multirow{2}{*}{ SEM } & \multirow{2}{*}{$P$ value } \\
\hline & Control & $0.4 \%$ OLP1 & $0.8 \%$ OLP2 & $1.2 \%$ OLP3 & $1.8 \%$ OLP4 & & \\
\hline \multicolumn{8}{|l|}{ 0-14 days } \\
\hline Initial weight $(\mathrm{g} / \mathrm{b})$ & 47.96 & 47.75 & 48.04 & 47.92 & 47.79 & 0.30 & 0.96 \\
\hline Final weight $(\mathrm{g} / \mathrm{b})$ & 355.67 & 360.75 & 364.17 & 356.29 & 367.19 & 8.83 & 0.90 \\
\hline $\operatorname{ADG}(\mathrm{g} / \mathrm{b} / \mathrm{d})$ & 21.98 & 22.36 & 22.58 & 22.03 & 22.82 & 0.63 & 0.90 \\
\hline $\operatorname{ADFI}(\mathrm{g} / \mathrm{b} / \mathrm{d})$ & 42.88 & 41.87 & 41.14 & 39.93 & 42.58 & 1.40 & 0.69 \\
\hline FCR & $1.96^{\mathrm{a}}$ & $1.88^{\mathrm{ab}}$ & $1.82^{\mathrm{b}}$ & $1.82^{\mathrm{b}}$ & $1.87^{\mathrm{ab}}$ & 0.02 & 0.03 \\
\hline \multicolumn{8}{|l|}{ 15-28 days } \\
\hline Initial weight $(\mathrm{g} / \mathrm{b})$ & 355.67 & 360.75 & 364.17 & 356.29 & 367.19 & 8.83 & 0.90 \\
\hline Final weight $(\mathrm{g} / \mathrm{b})$ & 1089.29 & 1127.65 & 1113.70 & 1125.21 & 1133.80 & 29.24 & 0.87 \\
\hline $\operatorname{ADG}(\mathrm{g} / \mathrm{b} / \mathrm{d})$ & $52.40^{\mathrm{b}}$ & $54.78^{\mathrm{a}}$ & $53.54^{\mathrm{ab}}$ & $54.92^{\mathrm{a}}$ & $54.76^{\mathrm{a}}$ & 0.42 & 0.03 \\
\hline $\operatorname{ADFI}(\mathrm{g} / \mathrm{b} / \mathrm{d})$ & 107.07 & 90.12 & 83.48 & 76.04 & 84.63 & 6.78 & 0.08 \\
\hline FCR & 2.26 & 2.04 & 2.21 & 1.68 & 2.01 & 0.25 & 0.62 \\
\hline \multicolumn{8}{|l|}{ 0-28 days } \\
\hline Initial weight $(\mathrm{g} / \mathrm{b})$ & 47.96 & 47.75 & 48.04 & 47.92 & 47.79 & 0.30 & 0.96 \\
\hline Final weight $(\mathrm{g} / \mathrm{b})$ & $1089.29^{b}$ & $1127.65^{\mathrm{a}}$ & $1113.70^{\mathrm{ab}}$ & $1125.21^{\mathrm{a}}$ & $1133.80^{\mathrm{a}}$ & 6.24 & 0.04 \\
\hline $\operatorname{ADG}(\mathrm{g} / \mathrm{b} / \mathrm{d})$ & $37.19^{\mathrm{b}}$ & $38.57^{\mathrm{a}}$ & $38.06^{\mathrm{ab}}$ & $38.47^{\mathrm{a}}$ & $38.78^{\mathrm{a}}$ & 0.31 & 0.04 \\
\hline ADFI $(\mathrm{g} / \mathrm{b} / \mathrm{d})$ & $74.97^{\mathrm{a}}$ & $66.29^{\mathrm{ab}}$ & $61.34^{\mathrm{b}}$ & $59.03^{\mathrm{b}}$ & $42.32^{c}$ & 3.38 & 0.001 \\
\hline FCR & $2.02^{\mathrm{a}}$ & $1.72^{\mathrm{b}}$ & $1.61^{\mathrm{b}}$ & $1.54^{\mathrm{b}}$ & $1.09^{c}$ & 0.09 & 0.001 \\
\hline
\end{tabular}

${ }^{\mathrm{a}, \mathrm{b}, \mathrm{c}}$ Means in a row with no common superscripts significantly differ $(\mathrm{P}<0.05)$.

${ }^{1}$ Data presented as the mean value of four replicate groups with eight birds per replication $(n=32)$.

$\mathrm{OLP}=$ Olive leaves probiotics; ADG = average daily gain; ADFI = average daily feed intake.

$\mathrm{SEM}=$ Standard error of the mean.

Table 4. Effect of dietary supplementation of OLP on hematological parameters.

\begin{tabular}{llllllll}
\hline \multirow{2}{*}{ Parameters } & \multicolumn{9}{c}{ Treatments } & \multirow{2}{*}{ SEM value } & \multirow{2}{*}{ P valu } \\
\cline { 2 - 6 } & Control & $\mathbf{0 . 4 \%}$ OLP1 & $\mathbf{0 . 8 \%}$ OLP2 & $\mathbf{1 . 2 \%}$ OLP3 & $\mathbf{1 . 8 \%}$ OLP4 & & \\
\hline Cholesterol (mg/dl) & $166.20^{\mathrm{b}}$ & $198.80^{\mathrm{ab}}$ & $185.87^{\mathrm{ab}}$ & $229.67^{\mathrm{a}}$ & $143.00^{\mathrm{b}}$ & 15.92 & 0.05 \\
TRG (mg/dl) & 39.91 & 64.78 & 46.58 & 31.94 & 41.43 & 9.00 & 0.22 \\
HDL (mg/dl) & $60.37^{\mathrm{bc}}$ & $87.09^{\mathrm{ab}}$ & $70.62^{\mathrm{abc}}$ & $92.90^{\mathrm{a}}$ & $46.88^{\mathrm{c}}$ & 7.37 & 0.01 \\
LDL & 97.85 & 98.76 & 105.93 & 130.38 & 87.84 & 9.94 & 0.15 \\
\hline
\end{tabular}

${ }^{a, b, c}$ Means in a row with no common superscripts significantly differ $(\mathrm{P}<0.05)$.

${ }^{1}$ Data presented as the mean value of four eplicate groups with two birds per replication $(n=8)$.

OLP = Olive leaves probiotics; $\mathrm{SEM}=$ Standard error of the mean.

Table 5. Effect of dietary supplementation of Olive leaves probiotics feed on carcass quality and internal organ weight of broiler.

\begin{tabular}{llllllll}
\hline \multirow{2}{*}{ Parameters } & \multicolumn{3}{c}{ Treatments } & \multirow{2}{*}{ SEM } & \multirow{2}{*}{ P value } \\
\cline { 2 - 6 } & Control & $\mathbf{0 . 4 \%}$ OLP1 & $\mathbf{0 . 8 \%}$ OLP2 & $\mathbf{1 . 2 \%}$ OLP3 & $\mathbf{1 . 8 \%}$ OLP4 & \\
\hline Dressed wt (g) & $68.23^{\mathrm{a}}$ & $60.15^{\mathrm{b}}$ & $66.97^{\mathrm{a}}$ & $70.34^{\mathrm{a}}$ & $68.57^{\mathrm{a}}$ & 1.54 & 0.03 \\
Breast meat wt (g) & $19.60^{\mathrm{a}}$ & $16.10^{\mathrm{c}}$ & $16.84^{\mathrm{bc}}$ & $19.24^{\mathrm{ab}}$ & $20.55^{\mathrm{a}}$ & 0.57 & 0.01 \\
Thigh meat (with bone) & 20.12 & 17.39 & 20.37 & 20.51 & 18.98 & 0.67 & 0.07 \\
Thigh meat wt & 15.64 & 13.21 & 15.46 & 16.00 & 14.60 & 0.68 & 0.14 \\
Thigh wt (g) & 4.02 & 3.79 & 4.61 & 4.24 & 4.05 & 0.18 & 0.33 \\
Thigh Length (cm) & $0.75^{\mathrm{ab}}$ & $0.73^{\mathrm{b}}$ & $0.82^{\mathrm{a}}$ & $0.79^{\mathrm{ab}}$ & $0.75^{\mathrm{b}}$ & 0.02 & 0.07 \\
Thigh width (mm) & 0.54 & 0.54 & 0.56 & 0.57 & 0.54 & 0.02 & 0.75 \\
Liver (g) & 2.32 & 2.72 & 2.33 & 2.72 & 2.33 & 0.14 & 0.14 \\
Gizzard (g) & 4.01 & 4.58 & 4.25 & 4.15 & 3.53 & 0.29 & 0.38 \\
Ceca (g) & $0.73^{\mathrm{b}}$ & $0.79^{\mathrm{ab}}$ & $0.93^{\mathrm{ab}}$ & $0.74^{\mathrm{ab}}$ & $1.17^{\mathrm{a}}$ & 0.11 & 0.16 \\
Total intestine (g) & 6.97 & 7.45 & 7.66 & 7.42 & 7.35 & 0.52 & 0.93 \\
Spleen (g) & 0.08 & 0.10 & 0.09 & 0.10 & 0.10 & 0.02 & 0.94 \\
Bursa (g) & $0.20^{\mathrm{ab}}$ & $0.13^{\mathrm{b}}$ & $0.28^{\mathrm{a}}$ & $0.19^{\mathrm{b}}$ & $0.17^{\mathrm{b}}$ & 0.02 & 0.04 \\
Abdominal fat (g) & 1.00 & 1.27 & 1.50 & 1.08 & 1.13 & 0.15 & 0.29 \\
\hline
\end{tabular}

${ }^{a, b, c}$ Means in a row with no common superscripts significantly differ $(\mathrm{P}<0.05)$.

Data presented as the mean value of four replicate groups with two birds per replication $(n=8)$.

$\mathrm{OLP}=$ Olive leaves probiotics; $\mathrm{SEM}=$ Standard error of the mean. 
Table 6. Effect of dietary supplementation of OLP on meat proximate composition.

\begin{tabular}{llllllll}
\hline \multirow{2}{*}{ Parameters } & \multicolumn{9}{c}{ Treatments } & \multirow{2}{*}{ SEM } & \multirow{2}{*}{ P value } \\
\cline { 2 - 6 } & Control & $\mathbf{0 . 4 \%}$ OLP1 & $\mathbf{0 . 8 \%}$ OLP2 & $\mathbf{1 . 2 \%}$ OLP3 & $\mathbf{1 . 8 \%}$ OLP4 & & 0.67 \\
\hline \% DM & 92.96 & 92.33 & 92.49 & 90.95 & 92.64 & 0.39 \\
\% CP & $22.05^{\mathrm{bc}}$ & $23.45^{\mathrm{a}}$ & $22.81^{\mathrm{ab}}$ & $23.04^{\mathrm{a}}$ & $21.65^{\mathrm{c}}$ & 0.24 & 0.01 \\
\% EE & 1.52 & 2.17 & 1.59 & 0.92 & 1.26 & 0.26 & 0.08 \\
$\%$ Ash & $1.44^{\mathrm{d}}$ & $1.62^{\mathrm{ab}}$ & $1.68^{\mathrm{a}}$ & $1.53^{\mathrm{c}}$ & $1.56^{\mathrm{bc}}$ & 0.02 & 0.0004 \\
\hline
\end{tabular}

${ }^{a, b, c}$ Means in a row with no common superscripts significantly differ $(\mathrm{P}<0.05)$.

${ }^{1}$ Data presented as the mean value of four replicate groups with two birds per replication $(n=8)$

$\mathrm{OLP}=$ Olive live probiotics, $\mathrm{DM}=$ Dry matter, $\mathrm{CP}=$ Crude protein, $\mathrm{EE}=$ Ether extract

$\mathrm{SEM}=$ Standard error of the mean.

Table 7. Analysis of cost and return of broiler rearing supplemented with olive leaves.

\begin{tabular}{|c|c|c|c|c|c|c|c|}
\hline \multirow[b]{2}{*}{ Parameters } & \multicolumn{5}{|c|}{ Treatments } & \multirow[b]{2}{*}{ SEM } & \multirow[b]{2}{*}{$P$ value } \\
\hline & Control & $\begin{array}{l}\text { OLP1 } \\
(0.4 \%)\end{array}$ & $\begin{array}{l}\text { OLP2 } \\
(0.8 \%)\end{array}$ & $\begin{array}{l}\text { OLP3 } \\
(1.2 \%)\end{array}$ & $\begin{array}{l}\text { OLP4 } \\
(1.8 \%)\end{array}$ & & \\
\hline $\begin{array}{l}\text { Total recurrent cost (Chick, } \\
\text { feed, labour, vaccine, } \\
\text { electricity, miscellaneous, } \\
\text { interest on operating capital } \\
\text { etc., BDT/bird) }\end{array}$ & $110.13^{\mathrm{a}}$ & $101.19^{b}$ & $97.87^{b}$ & $95.66^{b}$ & $82.20^{c}$ & 2.74 & 0.001 \\
\hline $\begin{array}{l}\text { Total fixed cost } \\
\text { (Housing, equipment etc., } \\
\text { BDT/bird) }\end{array}$ & 24.67 & 24.67 & 24.67 & 24.67 & 24.67 & 0.00 & 0.00 \\
\hline Total cost (BDT/bird) & $134.80^{\mathrm{a}}$ & $125.86^{\mathrm{b}}$ & $122.54^{\mathrm{b}}$ & $120.33^{\mathrm{b}}$ & $106.87^{\mathrm{c}}$ & 2.74 & 0.001 \\
\hline $\begin{array}{l}\text { Total return (Bird sale, } \\
\text { BDT/bird) }\end{array}$ & $141.61^{b}$ & $146.59^{\mathrm{a}}$ & $144.78^{\mathrm{ab}}$ & $146.28^{\mathrm{a}}$ & $147.40^{\mathrm{a}}$ & 0.81 & 0.038 \\
\hline Net return (BDT/bird) & $6.81^{\mathrm{c}}$ & $20.74^{\mathrm{b}}$ & $22.24^{\mathrm{b}}$ & $25.95^{\mathrm{b}}$ & $40.53^{\mathrm{a}}$ & 2.67 & $<.0001$ \\
\hline BCR & $1.05^{\mathrm{c}}$ & $1.16^{\mathrm{b}}$ & $1.18^{\mathrm{b}}$ & $1.22^{\mathrm{b}}$ & $1.38^{\mathrm{a}}$ & 0.03 & $<.0001$ \\
\hline
\end{tabular}

${ }^{a, b, c}$ Means in a row with no common superscripts significantly differ $(\mathrm{P}<0.05)$.

Data presented as the mean value of four replicate groups with 8 birds per replication $(n=32)$.

OLP = Olive leaf probiotics; $\mathrm{SEM}=$ Standard error of mean. $\mathrm{BCR}=$ Benefit cost ratio.

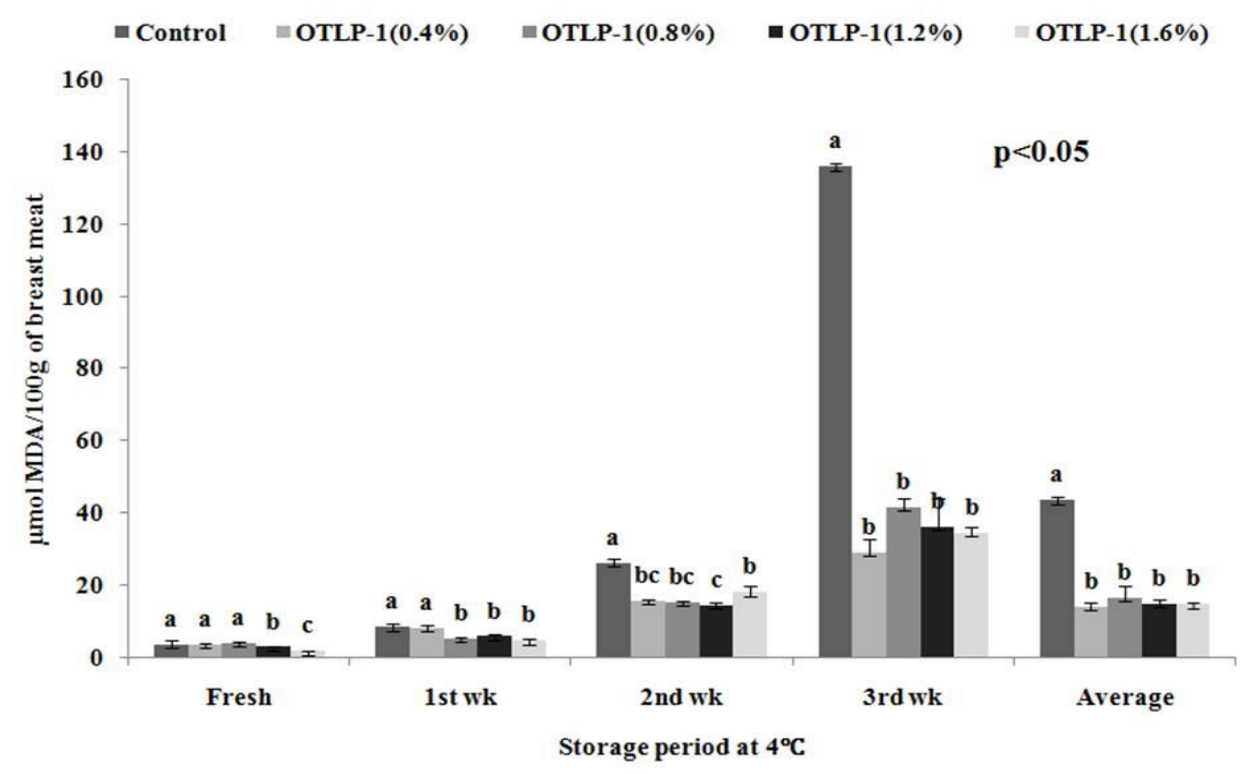

Figure 1. Effect of dietary supplementation of olive leaves probiotics feed on meat TBARS ( $\mu$ mol MDA/100g) in broiler.

$\left[{ }^{\mathrm{a}, \mathrm{b}, \mathrm{c}}\right.$ Means in a row with no common superscripts significantly differ $(\mathrm{P}<0.05)$. Data presented as the mean value of tree replicate groups with three birds per replication $(\mathrm{n}=9)$. OLP= Olive leaves probiotics.] 


\section{Conclusions}

The present study investigated the dietary effects of olive leaves fermented with probiotics on growth performance, carcass characteristics, blood parameters, meat quality and oxidative stability of meat in broiler. The results showed that, the weekly and overall live weight and ADG increased, FCR and ADFI decreased in dietary groups from control. No difference was observed in organ weight among the groups. The chemical composition of meat showed, there was a significant increase in meat crude protein and ash content in treatment groups compared to control. The blood HDL level increased in OLP 1, 2 and 3 treatment groups in comparison with control group. In treatment groups, the TBARS value reduced in every week except fresh sample with a significant reduction in overall period from control. Net return and BCR also found better in olive leave fermented supplementation than control. Therefore, a dietary supplement of olive leaves with probiotic fermentation can be used to improve growth performance, blood parameters, meat quality and oxidative stability of broiler meat with a better result when provided with $1.2 \%$ and $1.6 \%$ of the diet.

\section{Acknowledgements}

Authors are grateful to University Grants Commission of Bangladesh, UGC Bhaban, Agargaon, Sher-EBanglanagar, Dhaka-1207 for funding this unique research.

\section{Conflict of interest}

None to declare.

\section{References}

AOAC, 2000. Official methods of analysis of AOAC. International 17th edition; Gaithersburg, MD, USA Association of Analytical Communities.

Arrol S, MI Mackness and PN Durrington, 2000. Vitamin E supplementation increases the resistance of both LDL and HDL to oxidation and increases cholesteryl ester transfer activity. Atherosclerosis, 150: 129-134.

Biswas SK, A Chowdhury, J Das, A Chowdhury, SZ Raihan and MA Muhit, 2012. Phytochemical investigation with assessment of Cytotoxicity and Antibacterial activities of the ethanol extract of Elaeocarpus serratus. Am. J. Plant Physiol., 7: 47-52.

Chand AR and K Azeez, 2018. Evaluation of Essential and Toxic Metals in Selected Underutilized Fruits of Agasthyamala Biosphere Reserve, Kerala. Int. J. Agric. Environ. Biotechnol., 11: 319-326.

Das P, P Kar, S Hasnu, S Nath and B Tanti, 2017. Phytochemical screening and antioxidant activity of Elaeocarpus serratus L. of Assam. J. Pharmacogn. Phytochem., 6: 866-869.

Devatkal SK, K Narsaiah and A Borah, 2010. Anti-oxidant effect of extracts of kinnow rind, pomegranate rind and seed powders in cooked goat meat patties. Meat Sci., 85: 155-159.

Du M and DU Ahn, 2002. Effect of antioxidants on the quality of irradiated sausages prepared with turkey thigh meat. Poult. Sci., 81: 1251-1256.

Erener G, N Ocak, E Ozturk, S Cankaya, R Ozkanca and A Altop, 2020. Evaluation of olive leaf extract as a growth promoter on the performance, blood biochemical parameters, and caecal microflora of broiler chickens. R. Bras.Zootec., 49.

Fki I, Z Sahnoun and S Sayadi, 2007. Hypocholesterolemic effects of phenolic extracts and purified hydroxytyrosol recovered from olive mill wastewater in rats fed a cholesterol-rich diet. J. Agric. Food Chem. 55: 624-631.

Geetha DH, M Rajeswari and I Jayashree, 2013. Chemical profiling of Elaeocarpus serratus L. by GC-MS. Asian Pac. J. Trop. Biomed., 3: 985-987.

Herrero-Encinas J, M Blanch, JJ Pastor A Mereu, IR Ipharraguerre and D Menoyo, 2020. Effects of a bioactive olive pomace extract from Olea europaea on growth performance, gut function, and intestinal microbiota in broiler chickens. Poult. Sci., 99: 2-10.

Hossain MS, MC Sumy, S Ferdouse and MM Islam, 2019. Dietary effects of Dillenia indica leaves on growth performances, blood parameters, carcass characteristics and economic analysis in broilers. Bangladesh J. Vet. Anim. Sci., 7: 65-72.

Huang Y, X Wang, J Wang, F Wu, Y Sui, L Yang and Z Wang, 2013. Lactobacillus plantarum strains as potential probiotic cultures with cholesterol-lowering activity. J. Dairy Sci., 96: 2746-2753.

Jayashree I, DH Geetha and M Rajeswari, 2014. Evaluation of antimicrobial potential of Elaeocarpus serratus L. Int. J. Pharm. Sci. Res., 5: 3467-3472.

Jones R, 1984. A standard method of dissection for carcass analysis of poultry. Ayr, Scotlands: West of Scotland Agricultural Research. Technical Note No.: 222. 
Khaksefidi A and S Rahimi, 2005. Effect of probiotic inclusion in the diet of broiler chickens on performance, feed efficiency and carcass quality. Asian-Australas J. Anim. Sci., 18: 1153-1156.

Marangoni C, AJ Cichoski and JS Barin, 2017. Effect of olive leaves on the quality of chicken meat during frozen storage. Int. Food Res. J., 24: 164-172.

Mehr MA, MS Shargh, B Dastar, S Hassani and MR Akbari, 2007. Effect of different levels of protein and Protexin on broiler performance. Int. J. Poult. Sci., 6: 573-577.

Muaz K, M Riaz, S Akhtar, S Park, and A Ismail, 2018. Antibiotic residues in chicken meat: global prevalence, threats, and decontamination strategies: a review. J. Food Prot., 81: 619-627.

Nafea HH and MM Hussein, 2018. Effect of adding different levels of olive leaf powder to the diet on the production performance and some physiological characteristics of broilers. J. Res. Ecol., 6: 2176-2184.

National Research Council, 1994. Nutrient Require- ments of Poultry. 9th rev. ed. National Academy Press, Washington, DC.

NRC. 1984. Nutrition Requirements of Poultry. National Research Council, National Academy Press, Washington, DC. 33-34.

Oke OE, UK Emeshili, OS Iyasere, MO Abioja, JO Daramola, AO Ladokun, JA Abiona, TJ Williams, SA Rahman, SO Rotimi and SI Balogun, 2017. Physiological responses and performance of broiler chickens offered olive leaf extract under a hot humid tropical climate. J. Appl. Poult. Res., 26: 376-382.

Omar JMA, 2015. Carcass composition and visceral organ mass of broiler chicks fed different levels of olive pulp. IUG J. Nat. Stud., 13: 175-184.

Peng Q, XF Zeng, JL Zhu, S Wang, XT Liu, CL Hou, PA Thacker, and SY Qiao, 2016. Effects of dietary Lactobacillus plantarum B1 on growth performance, intestinal microbiota, and short chain fatty acid profiles in broiler chickens. Poult. Sci., 95: 893-900.

Podolian JN, 2017. Effect of probiotics on the chemical, mineral, and amino acid composition of broiler chicken meat. Ukr. J. Ecol., 7: 61-65.

Sateri S, A Seidavi, M Bouyeh, P Neumann, M Kutzler, V Laudadio, F Loperfido and V Tufarelli, 2017. Effect of olive meal and supplemental enzymes on performance traits, blood biochemistry, humoral immunity response and caecal microbiota of broilers. S. Afr. J. Anim. Sci., 47: 804-812.

Shafey TM, SI Almufarij and HA Albatshan, 2013. Effect of Feeding Olive Leaves on the Performance, Intestinal and Carcass Characteristics of Broiler Chickens. Int. J. Agric. Biol., 15: 585-589.

Wang Y, Y Wu, Y Wang, H Xu, X Mei, D Yu and W Li, 2017. Antioxidant Properties of Probiotic Bacteria. Nutrients, 9: 521-535.

Wasnaeni Y, A Iqbal and I Ismoyowati, 2015. Broiler Farmers' Behavior in Administering Antibiotic and Types of Antibiotic Content in Commercial Feed (A Case Study). Anim. Prod., 17: 62-68. 